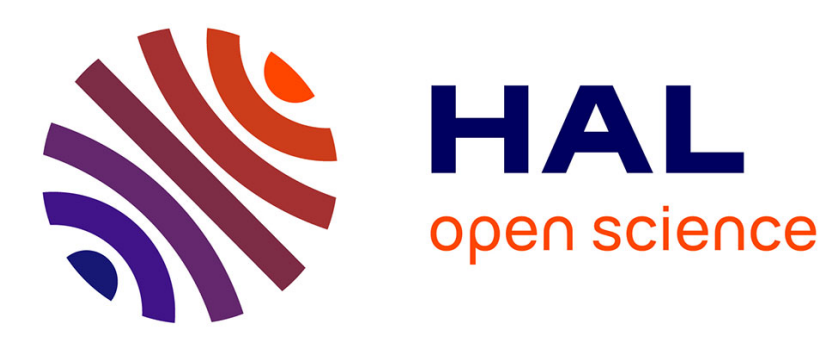

\title{
Fire severity as a key factor in post-fire regeneration of Pinus pinaster (Ait.) in Central Portugal
}

Maia, Juli Pausas, Vasques, Jan Keizer

\section{To cite this version:}

Maia, Juli Pausas, Vasques, Jan Keizer. Fire severity as a key factor in post-fire regeneration of Pinus pinaster (Ait.) in Central Portugal. Annals of Forest Science, 2012, 69 (4), pp.489-498. 10.1007/s13595-012-0203-6 . hal-00930852

\section{HAL Id: hal-00930852 https://hal.science/hal-00930852}

Submitted on 1 Jan 2012

HAL is a multi-disciplinary open access archive for the deposit and dissemination of scientific research documents, whether they are published or not. The documents may come from teaching and research institutions in France or abroad, or from public or private research centers.
L'archive ouverte pluridisciplinaire HAL, est destinée au dépôt et à la diffusion de documents scientifiques de niveau recherche, publiés ou non, émanant des établissements d'enseignement et de recherche français ou étrangers, des laboratoires publics ou privés. 


\title{
Fire severity as a key factor in post-fire regeneration of Pinus pinaster (Ait.) in Central Portugal
}

\author{
Paula Maia • Juli G. Pausas • Ana Vasques • \\ Jan Jacob Keizer
}

Received: 9 November 2011 / Accepted: 12 March 2012 /Published online: 9 May 2012

(C) INRA / Springer-Verlag France 2012

\begin{abstract}
- Context Mediterranean pine woodlands are strongly affected by wildfires; however, there are knowledge gaps in the role of fire severity on Pinus pinaster Ait. regeneration. - Objectives The principal questions were: (a) does post-fire regeneration of Maritime Pine differ where canopies were consumed to a low vs. high degree and (b) which factors, besides fire severity, could explain these differences.

- Methods Pine recruitment was monitored from 2 to 36 months after a summer wildfire in $1825 \mathrm{~m}^{2}$ plots, equally divided over two fire severity classes based on crown consumption. Besides the degree of crown consumption, three quantitative fire severity indices as well as post-fire site conditions, seed input and understory vegetation recovery were measured.

- Results Pine seedling densities were consistently higher in the plots with low than high crown consumption but due to marked spatial variability, they were only significantly different at two out of the eight sampling occasions. This variability could be explained by a quantitative index based
\end{abstract}

Handling Editor: Eric Rigolot

Contribution of the co-authors Paula Maia: experimental design, data collection, data analysis and paper write-up.

Juli Pausas: data analysis and statistical design, supervision and internal reviews.

Ana Vasques: data collection and internal reviews.

Jan Jacob Keizer: coordination of the project, experimental design, supervision and internal reviews.

P. Maia $(\bowtie) \cdot$ A. Vasques $\cdot$ J. J. Keizer

CESAM - Centre for Environmental and Marine Studies, Department of Environment and Planning, University of Aveiro, Aveiro, Portugal

e-mail: paula.maia@ua.pt

J. G. Pausas

CIDE-Centre for Research on Desertification, CSIC,

Valencia, Spain on the diameter of twigs, as well as by seed input and postfire site conditions (ash and litter cover).

- Conclusion Fire severity was found to strongly affect the pine recruitment following wildfire, using both a qualitative visual severity index and a quantitative, more labourintensive one.

Keywords Fire severity Pinus pinaster . Post-fire regeneration $\cdot$ Post-fire site conditions

\section{Introduction}

Pine woodlands are one of the Mediterranean Basin's ecosystems that are most affected by wildfires (Pausas et al. 2008), and their post-fire regeneration has been an important focus of scientific research over the past few decades (Pausas et al. 2004; Thanos and Skordilis 1987; Thanos et al. 1996; Trabaud et al. 1985). Pinus halepensis has been extensively studied in Spain, and it is now well established that the species' canopy seed bank is a key factor in its postfire regeneration (Eshel et al. 2000; Herranz et al. 1997; Pausas et al. 2003). Whilst $P$. halepensis is highly serotinous throughout the Iberian Peninsula (Tapias et al. 2004), Pinus pinaster (Maritime Pine) reveals marked variation in serotiny as well as in other fire-related characteristics within its geographical range (Barbéro et al. 1998; Gil et al. 2009; Tapias et al. 2004). Also, post-fire regeneration of $P$. pinaster has been studied less extensively than that of $P$. halepensis. Prior studies on post-fire recruitment of $P$. pinaster mainly concerned seed and cone traits as well as germination under controlled conditions (Alvarez et al. 2007; Fonturbel et al. 2011; Madrigal et al. 2010; Reyes and Casal 2001, 2004; Torres et al. 2006). The-few-studies that addressed post-fire recruitment of $P$. pinaster under field conditions were carried out in Spain (Calvo et al. 
2008; Vega et al. 2008, 2010), notwithstanding the fact that Maritime Pine woodlands are the most fire-prone forest type in Portugal (Silva et al. 2009).

Recently burnt areas generally comprise a mosaic of heterogeneous site conditions (Otto et al. 2010; Pausas et al. 2003; Ubeda et al. 2006; Vega et al. 2010), which can be expected to influence post-fire vegetation recovery. A key factor in this spatial variability is often the in situ fire severity (Otto et al. 2010; Pausas et al. 2003; Vega et al. 2008, 2010), but also other abiotic factors such as pre-fire forest management (Perez and Moreno1998) or topography (Pausas et al. 2004) can play a role. With respect to biotic factors, inter-specific competition by the understory vegetation was found to condition post-fire regeneration of Aleppo Pine populations, even from an early stage of recruitment (De las Heras et al. 2002; Nathan and Ne'eman 2004). In forest management, the understory vegetation is commonly regarded as having a negative impact on pine densities and growth and is, therefore, often (partially) eliminated. Nonetheless, positive effects of the understory on post-fire pine recruitment have also been suggested (Calvo et al. 2008; Trabaud et al. 1985).

The main aim of this study was to deepen the knowledge of the regeneration of Mediterranean pine woodlands following wildfires, in particular that of $P$. pinaster stands. The specific objectives were: (1) to quantify seedling recruitment of $P$. pinaster during the first 36 months after a wildfire; (2) to assess the role therein of key abiotic and biotic factors, in particular fire severity as evaluated using three distinct vegetation-based indices and recovery of the understory vegetation; and (3) to evaluate which of these three severity indices is most appropriate to predict post-fire pine regeneration and, thus, of most interest from a forest management point of view.

\section{Materials and methods}

\subsection{Study area}

The study area was located in Central Portugal, on the border of the municipalities of Góis and Arganil of the Coimbra District, near the village of Colmeal. A wildfire took place on 24 August 2008, burning in total some 60 ha. Within the burnt area, a west-facing slope of roughly 20 ha covered with $P$. pinaster Ait. $\left(40^{\circ} 08^{\prime}-45^{\circ} 77^{\prime} \mathrm{N}, 7^{\circ} 59^{\prime}-08^{\circ}\right.$ $22^{\prime} \mathrm{W}, 468-525$ ma.s.1.) was selected for this study. The study site was selected for revealing a rather homogeneous Maritime Pine cover before the wildfire, on one hand, and, on the other, a markedly heterogeneous fire impact, as suggested by well-defined differences in the consumption of the pine crowns. The pre-fire pine cover was observed on available satellite imagery (Google Earth) and aerial photography.
Vegetation relevees carried out in adjacent unburnt patches on the study slope suggested that before the wildfire, the understory vegetation was mainly composed of shrubs and grasses, in particular, Arbutus unedo L., Erica australis L., Calluna vulgaris (I.) Hull, Pterospartum tridentatum (L.) Willk and Phyllirea angustifolia L., Agrostis curtisii Kerguélen and Agrostis delicatula Pourr. ex Lapeyr (plant nomenclature following Tutin et al. (1964-1980)). In February 2009, the study site was logged and the fallen trunks were extracted for reasons of plague prevention. Logging of the sample plots, however, was done with utmost care and provoked no visible disturbance to the recovering vegetation. Various tree ring counts were carried out of the remaining trunks, indicating that at the time of the wildfire, the age of the pine stand was approximately 25 years. The level of serotiny of the stand was estimated by counting the closed and open cones in the canopies of 30 pine trees located immediately outside the burnt area and computed as the average percentage of closed cones.

The climate of the study area can be classified as MesoMediterranean (Rivas-Martínez et al. 2002). The mean annual temperature is estimated to be between 10 and $12.5^{\circ} \mathrm{C}$, and the average annual rainfall between 1,400 and 1,600 $\mathrm{mm}$ (SNIRH 2011). Two soil profiles excavated in different parts of the study site suggested that the soils are predominantly shallow Leptosols (WRB 2007), overlying preOrdovician schists of the Hercynian Massif (Ferreira 1978). The topsoil $(0-5 \mathrm{~cm})$ of these profiles had a sandy loam to loam texture (Santos 2010) (sand, 29-54 \%; silt, 29 $\%$; clay, 16-22\%).

\subsection{Experimental design}

The experimental design that was originally envisaged comprised three pairs of nearby transects with easily observed, contrasting fire severities; in this case, it was evidenced by different degrees of pine crown consumption. Photographs from the opposite side of the valley did allow selecting three zones, where pine crown consumption varied markedly over short distances. Dark-coloured patches were taken to reflect (almost) complete consumption of the pine crowns, whereas light-coloured patches were interpreted to correspond to scorched crowns, retaining substantial amounts of - deadneedles. However, in situ estimation of pine crown consumption (fully consumed crowns (FCC), see below) obliged to reclassify one of the dark-coloured patches as well as one of the light-coloured patches. Although the resulting experimental design continued to be balanced, it no longer involved paired transects of high and low crown consumption (HCC and LCC; Fig. 1).

The six transects were laid out in a perpendicular direction to the contour lines and on basically the same slope positions, so as to minimise differences in topographic and 


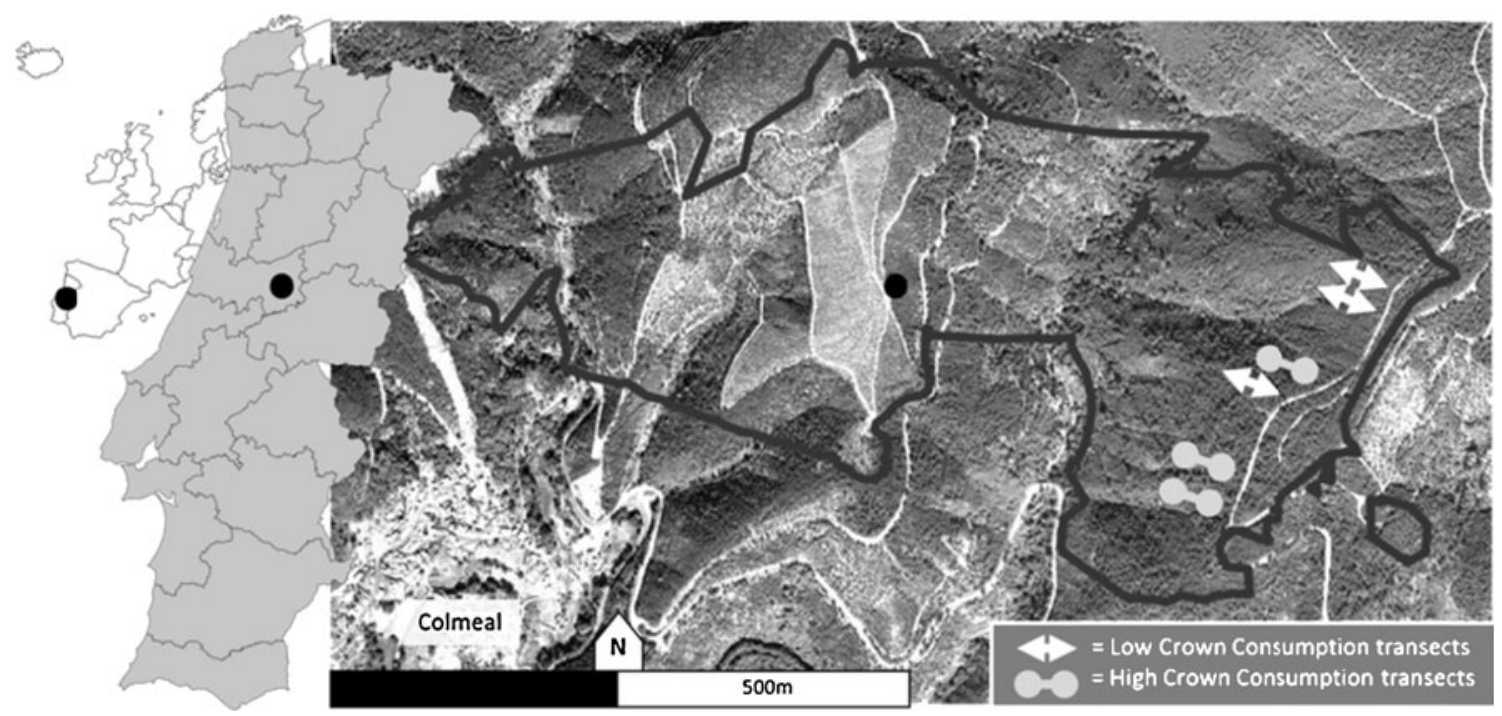

Fig. 1 Location of the study area and of the six transects with contrasting fire severities, classified as HCC and LCC of the Maritime Pine trees

soil conditions. They had a length of approximately $30 \mathrm{~m}$, along which three plots of $25 \mathrm{~m}^{2}$ were established at intervals of roughly $10 \mathrm{~m}$. In turn, each plot was subdivided in four subplots of 2.5 by $2.5 \mathrm{~m}$, which were separated by corridors of $1 \mathrm{~m}$ width to facilitate the monitoring of pine recruitment and vegetation recovery.

\subsection{Field measurements}

During the first 2 weeks after the wildfire, the pre-fire stand characteristics at each plot were described by measuring the diameter at breast height (DBH) and height of all standing trees. Simultaneously, fire severity was estimated based on: (a) height of flame marks on the pine trunks, expressed as the average ratio of flame height to total tree height (burnt trunk, BTR); (b) number of pine trees whose needles were all consumed by the fire, expressed as fraction of FCC; and (c) diameter of the three thinnest remaining twigs of five to ten randomly selected shrubs within each plot, expressed as ratio of average plot-wise diameter to the maximum value of the twig diameters measured in all 18 plots (twig severity index, TSI) (Maia et al. 2012). A possible limitation of the TSI was that the selected shrubs were not identified in terms of species (as would have been possible, albeit only at a later stage and just for the surviving shrubs). Finally, the number of pine cones lying on the ground within each plot was counted as an indicator of pine seed input. This was repeated in March 2009 to account for the impact of the logging. Pine seed input was further estimated by means of seed traps, following the design by Cottrell (2004) and consisting of a funnel with an orifice of $150 \mathrm{~cm}^{2}$ placed at $20 \mathrm{~cm}$ above ground level. At each plot, one seed trap was installed within the first 3 weeks after the wildfire and then monitored for seed rain at regular intervals. During the entire 36-month study period, however, none of the 18 traps caught any Maritime Pine seed.

Post-fire pine recruitment was first evaluated 2 months after the wildfire, in October 2008, and then repeated at seven occasions, with a decreasing frequency with increasing time since fire up till the end of this study in August 2011. At each occasion, all green pine seedlings/saplings within each plot were counted; at the last occasion, the saplings' heights were also measured. The October 2008 field campaign further involved estimating the horizontally projected ground covers of bare soil, ash and litter. This was done visually for each of the four subplots, estimating percentage cover to the nearest integer and then averaging them to arrive at the plot-wise values. The total cover of the understory vegetation (i.e. excluding the pine seedlings/saplings) as well as the cover of the individual plant species was estimated in the same manner but at two later occasions, in March 2010 and August 2011. The predominant mode in which each species regeneratedby resprouting or through germination-was assessed by careful visual inspection.

\subsection{Data analysis}

The two crown consumption classes were compared with respect to the observed pre-fire pine stand characteristics as well as the post-fire measurements of fire severity, ground cover, seed input, pine recruitment and understory vegetation recovery. This was done by means of nested analyses of variance (ANOVAs), with the plots nested under their respective transects, and using the univariate general linear model (GLM) procedure of SPSS (v.16). SPSS was further used to assess the agreement between the three fire severity indices, by means of the Spearman rank correlation coefficient. Likewise, the correlations of these indices with the 
covers of bare soil, ash and litter cover were determined, for the expected association on these site conditions with fire intensity. Finally, the SPSS procedure of univariate GLM regression was employed to determine which of the severity indices and post-fire site conditions could explain a significant part of the observed variation in post-fire vegetation recovery. Such variable(s) could then be applied in post-fire land management as simple predictor of pine recruitment in particular. The GLM regressions involved the same nested design as the ANOVAs.

The statistical analyses were carried out using ranktransformed values rather than the original values (McDonald 2009). This was done because the distributions of the various variables clearly deviated from normal and because a wide range of other transformations did not result in more satisfactory distributions.

\section{Results}

\subsection{Fire severity measures and post-fire site conditions}

All three fire severity indices presented, on average, noticeably higher values in the HCC plots than in the LCC plots
(Table 1). This difference was statistically significant in the case of the BTR ratio $(p=0.03)$ and the TWI $(p=0.03)$ but only marginally so in the case of the FCC $(p=0.06)$, due to a greater variability amongst the HCC plots in particular.

The ground covers of bare soil and ash immediately after the fire were, on average, markedly higher in the HCC than LCC plots, whereas the opposite was true for the litter cover (Table 1). Litter cover consisted by and large of pine needle cast from scorched pine crowns, attaining a particularly elevated value at the LCC plots $(75 \%)$. The HCC and LCC plots differed significantly in terms of bare soil $(p=$ $0.01)$ and litter cover $(p=0.04)$ but only marginally so in terms of ash cover $(p=0.07)$. This lack of significance reflected the comparatively low cover values of ash, combined with a relatively high spatial variability.

In line with their association with the two crown consumption classes, the three fire severity indices and the three ground cover variables were all strongly and significantly correlated one with each other (Table 2). The correlations between the severity indices, however, were less strong than those between the cover variables $\left(r_{\mathrm{s}}=0.84-0.97\right.$ vs. 0.49 0.68). Amongst the three severity indices, TSI was most closely associated with all three of the ground cover variables $\left(r_{\mathrm{s}}=0.74-0.76\right.$ vs. $\left.0.59-0.71\right)$.

Table 1 Mean values, standard deviations and nested ANOVA $p$ values for the various vegetation, site and fire severity characteristics determined at the nine high and nine low crown consumption plots

\begin{tabular}{|c|c|c|c|c|c|c|c|}
\hline & & & \multicolumn{4}{|c|}{ Crown consumption (CC) } & \multirow{3}{*}{$\begin{array}{l}\text { Nested ANOVA } \\
p \text { value }\end{array}$} \\
\hline & & & \multicolumn{2}{|c|}{ High CC } & \multicolumn{2}{|c|}{ Low CC } & \\
\hline & & & Mean & SD & Mean & SD & \\
\hline \multirow{2}{*}{\multicolumn{2}{|c|}{ Pre-fire stand characteristics }} & Standing pine trees $\left(\mathrm{nr} \mathrm{m}^{-2}\right)$ & 0.25 & 0.16 & 0.28 & 0.16 & 0.46 \\
\hline & & $\mathrm{DBH}(\mathrm{cm})$ & 33 & 5 & 35 & 5 & 0.76 \\
\hline \multirow{3}{*}{\multicolumn{2}{|c|}{ Fire severity indices }} & FCC & 0.29 & 0.18 & 0.06 & 0.10 & 0.06 \\
\hline & & BTR & 0.99 & 0.00 & 0.77 & 0.29 & 0.03 \\
\hline & & TSI & 0.39 & 0.08 & 0.21 & 0.13 & 0.03 \\
\hline \multirow{3}{*}{\multicolumn{2}{|c|}{ Post-fire site conditions ( $\%$ cover) }} & Bare soil & 34 & 8 & 8 & 4 & 0.01 \\
\hline & & Ash & 46 & 11 & 17 & 20 & 0.07 \\
\hline & & Litter & 20 & 19 & 75 & 23 & 0.04 \\
\hline \multirow{2}{*}{\multicolumn{2}{|c|}{ Pine seed input ( $\mathrm{nr}$ cones $\mathrm{m}^{-2}$ ) }} & Post-fire & 0.03 & 0.05 & 0.11 & 0.07 & 0.01 \\
\hline & & Post-harvest & 0.16 & 0.17 & 0.12 & 0.17 & 0.10 \\
\hline \multirow[t]{8}{*}{ Vegetation regeneration } & Pine seedling/saplings $\left(\mathrm{nr} \mathrm{m}^{-2}\right)$ & 2 months & 0.07 & 0.10 & 0.12 & 0.08 & 0.29 \\
\hline & & 18 months & 0.58 & 0.43 & 1.39 & 0.71 & 0.07 \\
\hline & & 36 months & 0.53 & 0.40 & 1.31 & 0.64 & 0.05 \\
\hline & Pine sapling height $(\mathrm{cm})$ & 36 months & 71 & 30 & 68 & 13 & 0.61 \\
\hline & Understory vegetation cover (\%) & Resprouting-18 months & 7 & 4 & 8 & 6 & 0.96 \\
\hline & & Germinating -18 months & 6 & 2 & 4 & 3 & 0.01 \\
\hline & & Resprouting-36 months & 24 & 11 & 28 & 15 & 0.93 \\
\hline & & Germinating-36 months & 15 & 7 & 16 & 7 & 0.37 \\
\hline
\end{tabular}

The significant differences at $\alpha=0.05$ were given in bold

$D B H$ diameter at breast height 
Table 2 Spearman rank correlation coefficients and corresponding $p$ values for the three fire severity indices and the three descriptors of post-fire site conditions at the 18 study plots

The significant coefficients at $\alpha=0.05$ were given in bold

\begin{tabular}{|c|c|c|c|c|c|c|}
\hline & & \multicolumn{3}{|c|}{$\begin{array}{l}\text { Post-fire site conditions } \\
\text { (\% ground cover) }\end{array}$} & \multicolumn{2}{|c|}{ Fire severity indices } \\
\hline & & Bare soil & Ash & Litter & TSI & BTR \\
\hline \multirow[t]{4}{*}{ Fire severity indices } & FCC & 0.62 & 0.59 & -0.59 & 0.49 & 0.56 \\
\hline & & $<0.01$ & 0.01 & 0.01 & 0.04 & 0.02 \\
\hline & BTR & 0.71 & 0.65 & -0.64 & 0.68 & \\
\hline & TSI & $<0.01$ & $<0.01$ & $<0.01$ & $<0.01$ & \\
\hline \multirow[t]{2}{*}{ Post-fire conditions ( $\%$ ground cover) } & Litter & $\begin{array}{l}-\mathbf{0 . 9 7} \\
<0.01\end{array}$ & $\begin{array}{l}-\mathbf{0 . 9 2} \\
<0.01\end{array}$ & & & \\
\hline & Ash & $\begin{array}{l}\mathbf{0 . 8 4} \\
<0.01\end{array}$ & & & & \\
\hline
\end{tabular}

\subsection{Pine seedling densities}

Pine recruitment followed a similar evolution at the HCC and LCC plots (Fig. 2). Four phases could be identified: (a) an initial increase in pine densities between October 2008 and January 2009; (b) a decrease between January and March 2008, which was attributed to the logging of the stand in February 2008; (c) a second increase between March and August 2008; and (d) stable densities between August 2009 and August 2011.

Pine seedling/sapling densities were, on average, consistently higher at the LCC than HCC plots throughout the study period. These differences were statistically significant only at two occasions, i.e. 5 months after the fire in January 2009 and 3 years after the fire in August 2011 (nested ANOVA: $p=0.04$ and 0.05 , respectively). Nonetheless, they were marginally significant during the entire fourth phase of stable densities from August 2009 onwards, as illustrated for March 2010 in Table 1. The lack of significant differences during this final phase was due to the elevated spatial variability in pine recruitment, especially at the HCC plots with coefficients of variation amounting to roughly $75 \%$.

The spatial variation in pine recruitment could be explained reasonably well by one of the fire severity indices in particular, i.e. TSI (Table 3). At three distant periods after the wildfire (2, 18 and 36 months), TSI could account for a fraction of this variation that was marginally significant (GLM: $p=0.05-$ 0.09). Two of the ground cover variables, however, had a significant effect on pine seedling/sapling densities at all three occasions (Table 3 ). From these two, ash cover consistently revealed a stronger relationship with pine recruitment than litter cover (GLM: $p=<0.01-0.01$ vs. $0.01-0.04$ ).
Fig. 2 Average densities, and their standard deviations, of Pinus pinaster seedlings/ saplings at the HCC and LCC plots along the 36-month study period following the wildfire in August 2008. The two instances of significant differences, at $\alpha=$ 0.05 , between the HCC and LCC plots were indicated with an octagonal with "s"

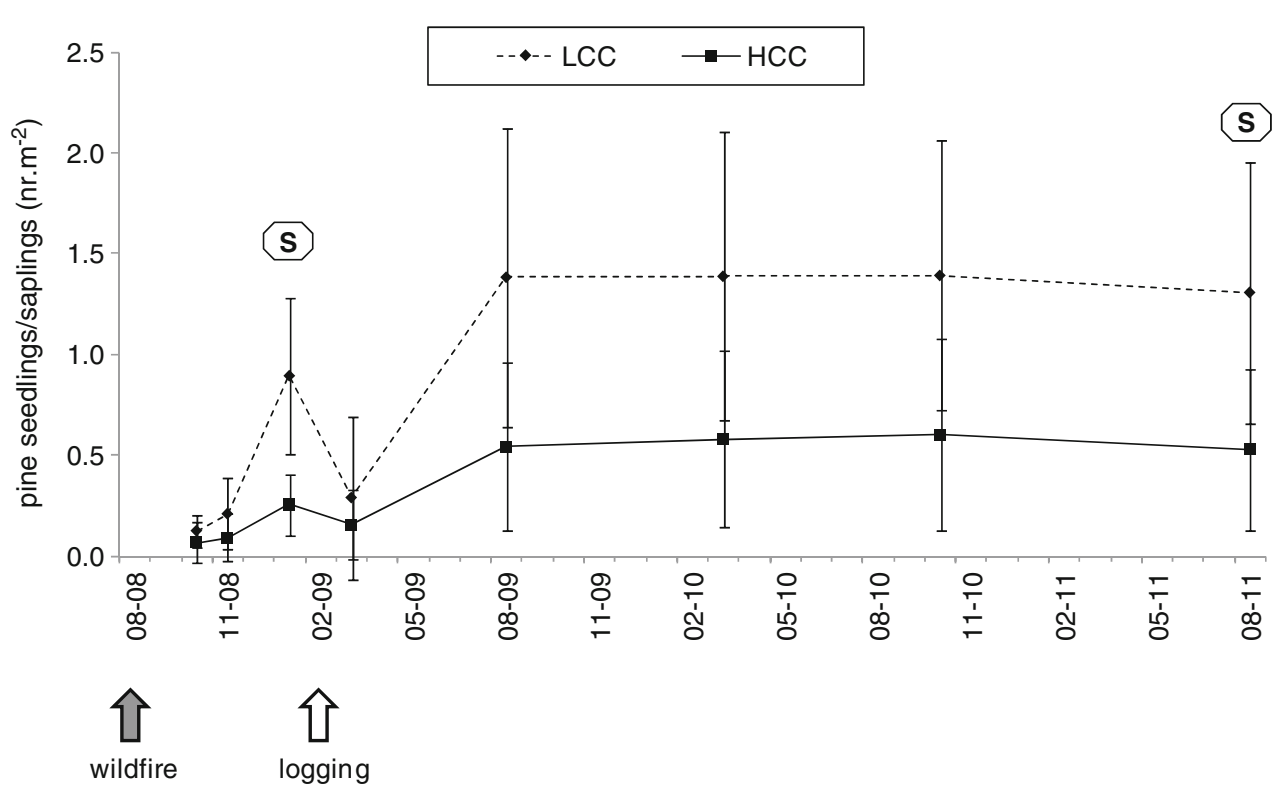


Table 3 GLM univariate regression results linking pine recruitment and understory regeneration to fire severity, post-fire site conditions and pine seed input

\begin{tabular}{|c|c|c|c|c|c|c|c|c|c|c|}
\hline & & & \multicolumn{8}{|c|}{ Explanatory variables } \\
\hline & & & \multirow[b]{2}{*}{ FCC } & \multirow[b]{2}{*}{ BTR } & \multirow[b]{2}{*}{ TSI } & \multirow[b]{2}{*}{ Bare soil } & \multirow[b]{2}{*}{ Ash } & \multirow[b]{2}{*}{ Litter } & \multicolumn{2}{|c|}{$\begin{array}{l}\text { Pine seed input } \\
\left(\mathrm{nr} \text { cones } \mathrm{m}^{-2}\right)\end{array}$} \\
\hline & & & & & & & & & Post-fire & $\begin{array}{l}\text { Post- } \\
\text { harvest }\end{array}$ \\
\hline \multirow{8}{*}{$\begin{array}{l}\text { Vegetation } \\
\text { regeneration }\end{array}$} & \multirow{3}{*}{$\begin{array}{l}\text { Pine seedlings/ } \\
\text { saplings } \\
\left(\mathrm{nr} \mathrm{m}^{-2}\right)\end{array}$} & 2 months & n.s. & n.s. & $\sim \mathrm{S}(-) 0.09$ & $\sim \mathrm{s}(-) 0.08$ & s $(-)<0.01$ & s (+) 0.04 & \multirow{8}{*}{$\begin{array}{l}\text { n.s. } \\
\text { s (+) } \mathbf{0 . 0 2} \\
\text { s (+) } \mathbf{0 . 0 2}\end{array}$} & \\
\hline & & 18 months & n.s. & n.s. & $\sim \mathrm{S}(-) 0.05$ & $\sim \mathrm{s}(-) 0.06$ & $\sim s(-) 0.01$ & s (+) 0.03 & & n.s. \\
\hline & & 36 months & $\sim \mathrm{S}(-) 0.09$ & n.s. & $\sim \mathrm{S}(-), 0.06$ & $\mathrm{~s}(-) 0.03$ & s $(-)<0.01$ & s (+) 0.01 & & n.s. \\
\hline & Pine height (cm) & 36 months & n.s. & n.s. & n.s. & n.s. & n.s. & n.s. & & \\
\hline & \multirow{4}{*}{$\begin{array}{l}\text { Understory } \\
\text { vegetation } \\
\text { cover }(\%)\end{array}$} & $\begin{array}{l}\text { Resprouting- } \\
36 \text { months }\end{array}$ & n.s. & n.s. & n.s. & n.s. & n.s. & n.s. & & \\
\hline & & $\begin{array}{l}\text { Germinating- } \\
18 \text { months }\end{array}$ & n.s. & s $(+)<0.01$ & s (+) 0.04 & $\sim \mathrm{S}(+), 0.08$ & n.s. & n.s. & & \\
\hline & & $\begin{array}{l}\text { Resprouting- } \\
36 \text { months }\end{array}$ & n.s. & n.s. & n.s. & n.s. & n.s. & n.s. & & \\
\hline & & $\begin{array}{l}\text { Germinating- } \\
36 \text { months }\end{array}$ & n.s. & n.s. & n.s. & n.s. & n.s. & n.s. & & \\
\hline
\end{tabular}

The significant (at $\alpha=0.05$ ) and marginally significant $(\alpha=0.05-0.10)$ correlations were indicated by " $\mathrm{s}$ " in bold and " $\sim \mathrm{s}$ ", respectively, followed by the sign of the correlation coefficient and the $p$ values

\subsection{Pine seed input}

Pine cone density could explain the spatial variation in pine recruitment to a significant extent (Table 3). This role of pine seed input involved a time lag, however. The pine seedling/sapling densities 18 and 36 months after the wildfire were significantly related to the cone densities in September 2008 (GLM: $p s=0.02$ ) but not to the cone densities in March 2009, after the logging. Also, the seedling/sapling densities 2 months after the wildfire revealed no significant influence of the cone densities immediately after the fire.

The density of pine cones lying on the ground within the plots was, on average, twice as high in March 2009, after the logging, than in September 2008, immediately after the wildfire ( 0.07 vs. 0.14 cones $\mathrm{m}-2)$. This increase, however, was marginal in the case of the LCC plots as opposed to that of the HCC plots (Table 1). Whilst the LCC plots contained significantly more cones than the HCC plots in September 2008, they contained markedly less in March 2009, albeit not significantly.

\subsection{Pine sapling heights}

Three years after the wildfire, the pine saplings had, on average, attained basically the same height in the HCC and LCC plots, i.e. approximately $70 \mathrm{~cm}$. Like in the case of the pine densities, the HCC plots revealed a greater spatial variability in pine height than the LCC plots (coefficient of variation $=40$ vs. $20 \%$ ). Sapling height lacked apparent relationships with any of the fire severity indices or immediate post-fire site conditions (Table 3) and was also not significantly correlated with the concurrent sapling densities $(p=0.83)$.

\subsection{Regeneration of the understory vegetation}

The regeneration of the understory vegetation 18 and 36 months after the wildfire was similar for the LCC and HCC plots, in terms of: (a) overall covers; (b) the covers of germinating as well as resprouting species; and (c) the predominance of resprouting over germinating species, particularly at the end of the study period (Table 1). The only significant difference was that in the cover of the germinating species in March 2010, being slightly higher in the HCC than LCC plots (6 vs. $4 \%$ ). This fact was also evidenced by the GLM results, with two of the fire severity indices explaining a significant fraction of the variation in the March 2010 cover of the germinating species (Table 3). There were no clear suggestions that understory regeneration influenced pine recruitment, as covers were not significantly correlated with either pine densities or pine heights $(p s \geq 0.10)$. 
The understory vegetation of the HCC and LCC plots also differed little in species composition (Appendix 1). Various species, however, attained markedly different covers in the two types of plots at both sampling occasions. Amongst the resprouting species, E. australis was clearly more abundant in the HCC than LCC plots, whilst the opposite was true for $P$. tridentatum and $A$. curtisii. Amongst the germinating species, the principal difference was that in Cistus psilosepalus.

\section{Discussion}

This study revealed marked temporal as well as spatial variation in pine recruitment following a wildfire. Pine densities took approximately 1 year to reach maximum levels but revealed no major net changes afterwards. Maximum densities could be attained even quicker in the absence of logging, as suggested by the marked dieback in pine seedling between January and March 2009. On the other hand, there was no suggestion of seasonal variation in pine densities, at least during the second year following wildfire. Seasonal decreases in pine densities were reported by Martínez-Sanchez et al. (1999) but for $P$. halepensis and under more arid conditions. Also, pine recruitment in this study did not involve extreme weather conditions (Pausas et al. 2003) or apparent signs of plague attack (Vega et al. 2010).

Fire severity played a significant role in the spatial variability in pine recruitment. This pattern could be captured by the two classes of HCC and LCC, notwithstanding the classification's qualitative and somewhat subjective nature. Possibly, logging masked the association of HCC/LCC with pine densities in two different manners: (a) by provoking more dieback in the LCC than HCC plots and (b) by enhancing spatial variability in pine densities, especially amongst the HCC plots. This latter effect would seem to be long-lasting, at least 2.5 years (as differences were significant 36 months after the wildfire) and probably even considerably longer (as the coefficients of variation continued high 36 months after the fire).

Amongst the more quantitative proxies of fire severity studied here, litter and ash cover could best explain the spatial variability in pine densities. The relationship of pine densities with these two cover variables was furthermore less susceptible to changes through time than the relationship with the HCC/LCC. In the present case, ash and litter covers were almost perfectly correlated and, thus, could be used interchangeably for predicting pine recruitment. Prior studies, however, suggested that an effect of litter cover would be more consensual than one of ash cover. Whilst post-fire soil conditions are widely held to play a key role in the successful germination and early establishment of pines (e.g. Pausas et al. 2003; Madrigal et al. 2010; Vega et al. 2008), litter cover was reported to enhance pine recruitment in various manners, including through the accumulation of seeds, their protection against predators and surface wash and an increased nutrient availability (Bonnet et al. 2004; Denham et al. 2009; Fernández et al. 2008, 2011; Garcia Fayos and Cerda 1997; Saracino et al. 1997). Ash cover, on the other hand, was found to have, like here, a negative effect on pine density by Ne'eman and Izhaki (1998) as well as by Reyes and Casal $(2001,2004)$ but a positive effect by Pausas et al. (2003). From a purely practical point of view, litter cover would seem easier and quicker to estimate than ash cover. A first estimation of litter cover could then be obtained — even more easily and quickly — by means of the two crown consumption classes, as justified by the logical as well as statistical link between litter cover and needle cast from scorched crowns. Prior studies such as Otto et al. (2010), Pausas et al. (2003) and Vega et al. (2010) likewise related heterogeneous site conditions to fire severity classified according to the degree of crown consumption.

Pine recruitment in this study did not seem to be affected by the understory vegetation. This could be due to the low cover attained by the understory vegetation but also to the low density of pine seedlings. The latter would be in line with the findings of Calvo et al. (2008) that the density of pine seedlings was a determining factor for the interespecific competition with the understory species. Pausas et al. (2003), on the other hand, reported that post-fire recruitment of $P$. halepensis could be limited by high covers of resprouters, in particular gramineous species. Whilst the cover of the gramineous species in this study was low (HCC plots) to insignificant (LCC plots), inter- and intra-competition could be less intense due to the much less arid conditions than in the case of Pausas et al. (2003).

Pine recruitment was found here to reflect differences in seed input in the form of cones lying on the forest floor immediately after the wildfire. These differences in pine cones were, in turn, associated with fire severity. Apparently, the high consumption of the crowns also resulted in more cones being fully combusted than the low crown consumption did. HCC could further have produced a greater mortality in the aerial seed bank than LCC (Reyes and Casal 2002). The effect of pine cone density, however, revealed a clear time lag, suggesting that seed release from the cones mainly occurred in the early stages following wildfire, on one hand, and, on the other, that the released seeds germinated over a period of at least 1 year. The importance of the initial 
post-fire period for seed release was also indicated by the lack of a significant impact of the changes in pine cone densities that had occurred after logging.

Possibly, the principal release of pine seeds occurred after the cones had been shed from the canopies. Especially in the case of the LCC plots, temperatures might not have increased sufficiently to enable a quick and even seed release (Reyes and Casal 2002). This possibility would seem to agree well with the results of the seed traps, indicating the total absence of pine seed rain, at least from 3 weeks after the fire onwards. Such a lack of pine seed rain could relate to the timing of the wildfire-having occurred before the end of August, in line with García-Fayos et al. (2001) - in combination with the low level of serotiny of the studied population $(20 \%)$. Nonetheless, the number and size of the seed traps employed here might not have been entirely sufficient (Vega et al. 2010) and should ideally have been installed sooner after the fire. Also, a comparison of the spatial patterns in cone and seedling locations might have shed further light on the timing of seed release.

Pine recruitment 3 years after the Colmeal wildfire amounted, on average, to 0.9 pine saplings $/ \mathrm{m}^{2}$ and in no case exceeded 2.5 saplings $/ \mathrm{m}^{2}$. These figures were well below those reported by Vega et al. (2010) $\left(7\right.$ pines $\left./ \mathrm{m}^{2}\right)$ and especially Calvo et al. (2008) (12 pines $\left./ \mathrm{m}^{2}\right)$. This could be due to differences in serotiny, as Calvo et al. (2008) studied a highly serotinous population. Although the pine recruitment densities observed here were low compared to those reported by studies in Spain (Calvo et al. 2008; Vega et al. 2008, 2010), they did clearly exceed the pre-fire stand densities, i.e. with a factor of 2 to 4 . They were also substantially higher than the standard densities for 10-yearold pine stands (Oliveira 2000; 1,000 to 1,500 plants/ha). Thus, except for changes in the observed trend of stable sapling densities after the first post-fire year, pine densities in the study area would, from a forest management point of view, need to be thinned out substantially in the next 3 years (Oliveira 2000), especially in the slope parts where fire severity was lowest. On the other hand, there was no suggestion of the need for management of the understory vegetation, not only because of the aforesaid excess of pine saplings but also because of its apparent lack of influence on pine densities as well as sapling height.

\section{Conclusions}

Fire severity, as evidenced by the degree of crown consumption of the pine trees as well as by various severity indices related to soil surface properties (ash and litter covers) and damage of shrubs (twig severity index), was highlighted as a key factor in post-fire pine recruitment of Maritime Pine in Central Portugal. This emphasised the importance of viewing recently burnt areas as heterogeneous rather than homogeneous management units. At the same time, this study demonstrated the potential of simple indices of fire severity for assessing post-fire pine recruitment, even though the need for further testing in other recently burnt areas is more than obvious. Likewise, logging seemed to provoke an important dieback in pine seedlings but the longer-term effects could not be assessed.

Pine recruitment was significantly higher following lower than higher fire severity. This could be attributed first and foremost to a combined effect of less damage to the canopy seed bank and of forest floor conditions more propitious to seedling germination and early establishment. Pine height growth, on the other hand, was not affected by the differences in fire severity. The same was grosso modo true for the regeneration of understory vegetation, so that there was also no evidence for competition with pine regeneration.

Acknowledgments Our thanks go to all those people who, in many ways, helped with the field work, in particular Carli Mertopawiro, RoelToonen, Hein Vermin, Diana Vieira, Helga Fernandes, Isabel Fernandes and "Polly" Jingxian Tao. We also thank the Portuguese National Forestry Authority and the Technical Forestry Office (GTF) of Arganil Municipality for their authorization to work in the study area, the GTF of Góis Municipality for the information on the burnt area and the "Junta de Freguesia" of Colmeal for their logistic support. We finally want to acknowledge the contribution of two anonymous reviewers in improving this manuscript.

Funding P. Maia and A. Vasques were funded through PhD grants attributed by the Portuguese Foundation for Science and Technology (FCT), with references SFRH/BD/42168/2007 and SFRH/BD/47522/ 2008, respectively. The EROSFIRE II project, which provided logistic support in the bulk of the field campaigns, was also funded by the FCT, with co-funding by FEDER through the POCI2010 Programme (PTDC/AGR-CFL/70968/2006).

\section{Appendix 1}

Average and standard deviation of the cover (in percent) of the understory plant species at the nine high and nine low crown consumption plots 


\begin{tabular}{|c|c|c|c|c|c|c|c|c|c|c|}
\hline & & & \multicolumn{4}{|c|}{18 months post-fire } & \multicolumn{4}{|c|}{36 months post-fire } \\
\hline & & & \multirow{2}{*}{\multicolumn{2}{|c|}{$\begin{array}{l}\text { High crown } \mathrm{C} \text {. } \\
\text { Cover }(\%)\end{array}$}} & \multirow{2}{*}{\multicolumn{2}{|c|}{ Low crown C. }} & \multirow{2}{*}{\multicolumn{2}{|c|}{ High crown $\mathrm{C}$. }} & \multirow{2}{*}{\multicolumn{2}{|c|}{ Low crown $\mathrm{C}$. }} \\
\hline & & & & & & & & & & \\
\hline & & & Mean & SD & Mean & $\mathrm{SD}$ & Mean & $\mathrm{SD}$ & Mean & SD \\
\hline \multirow[t]{9}{*}{ Resprouting } & Ericacea & Arbutus unedo L. & 3 & 2 & 3 & 3 & 6 & 4 & 8 & 8 \\
\hline & Ericacea & Erica australis L. & 2 & 3 & 1 & 1 & 7 & 7 & 4 & 4 \\
\hline & Fabaceae & Pterospartum tridentatum (L.) Willk & 1 & 1 & 2 & 3 & 4 & 4 & 7 & 9 \\
\hline & Fagaceae & Quercus suber L. & 0 & 1 & - & & 1 & 1 & - & \\
\hline & Hypolepid & Pteridium aquilinum L. (Kuhn) & - & & 1 & 2 & 4 & 9 & 4 & 6 \\
\hline & Liliaceae & Scilla monophyllos Link. & 0 & 0 & 0 & 0 & - & & - & \\
\hline & Liliaceae & Simethis mattiazzi (Vandelli) Sacc. & 0 & 0 & 0 & 0 & 0 & 0 & 0 & 0 \\
\hline & Oleaceae & Phyllirea angustifolia L. & 0 & 1 & - & & 1 & 2 & - & \\
\hline & Poaceae & Agrostis curtisii Kérguelen & - & & 1 & 4 & 0 & 1 & 6 & 9 \\
\hline \multirow[t]{7}{*}{ Germinating } & Cistaceae & Cistus psilosepalus Sweet & 1 & 1 & 0 & 0 & 3 & 3 & 1 & 2 \\
\hline & Cistaceae & Halimium halimifolium (L.) Willk & 2 & 2 & 0 & 0 & 3 & 2 & 3 & 4 \\
\hline & Ericacea & Calluna vulgaris L. & 1 & 0 & 1 & 2 & 7 & 4 & 9 & 4 \\
\hline & Ericacea & Erica cinerea L. & - & & - & & 1 & 2 & 1 & 2 \\
\hline & Ericacea & Erica umbellata L. & - & & - & & - & & 0 & 1 \\
\hline & Salicaceae & Salix sp. & - & & 0 & 0 & 0 & 0 & 1 & 1 \\
\hline & & Annual and biennial herbs & 3 & 3 & 2 & 1 & 2 & 2 & 1 & 1 \\
\hline
\end{tabular}

\section{References}

Ferreira AdB (ed) (1978) Planaltos e montanhas do norte da Beiraestudo de geomorfologia. Centro de Estudos Geográficos, Lisbon

Alvarez R, Valbuena L, Calvo L (2007) Effect of high temperatures on seed germination and seedling survival in three pine species (Pinus pinaster, P. sylvestris and $P$. nigra). Int J Wildland Fire 16:63-70

Bonnet VH, Schoettle AW, Shepperd WD (2004) Spatial distribution of ponderosa pine seedlings along environmental gradients within burned areas in the Black Hills, South Dakota. USDA Forest Service Proceedings RMRS-P-34, Fort Collins, CO

Barbéro M, Loisel R, Quézel P, Richardson DM, Romane F (1998) Pines of the Mediterranean basin. In: Richadson DM (ed) Ecology and biogeography of Pinus. Cambridge University Press, Cambridge, pp $3-46$

Calvo L, Santalla S, Valbuena L, Marcos E, Tarrega R, Luis-Calabuig E (2008) Post-fire natural regeneration of a Pinus pinaster forest in NW Spain. Plant Ecol 197:81-90

Cottrell TR (2004) Seed rain traps for forest lands: considerations for trap construction and study design. BC Journal of Ecosystems and Management 5:1-6

De las Heras J, Martínez-Sánchez JJ, González-Ochoa AI, Ferrandis P, Herranz JM (2002) Establishment of Pinus halepensis Mill. sapling following fire: effects of competition with shrub species. Acta Oecol 23:91-97
Denham AJ, Whelan RJ, Auld TD (2009) Characterizing the litter in postfire environments: implications for seedling recruitment. Int $\mathbf{J}$ Plant Sci 170:53-60

Eshel A, Henig-Sever N, Ne'eman G (2000) Spatial variation of seedling distribution in an east Mediterranean pine woodland at the beginning of post-fire succession. Plant Ecol 148:175182

Fernandez C, Vega JA, Jimenez E, Fonturbel T (2011) Effectiveness of three post-fire treatments at reducing soil erosion in Galicia (NW Spain). Int J Wildland Fire 20:104-114

Fernández C, Vega JA, Fonturbel T, Jiménez E, Pérez-Gorostiaga $P$ (2008) Effects of wildfire, salvage logging and slash manipulation on Pinus pinaster Ait. recruitment in Orense (NW Spain). For Ecol Manag 255(3-4):1294-1304

Fonturbel MT, Vega JA, Perez-Gorostiaga P, Fernandez C, Alonso M, Cuinas P, Jimenez E (2011) Effects of soil burn severity on germination and initial establishment of maritime pine seedlings, under greenhouse conditions, in two contrasting experimentally burned soils. Int J Wildland Fire 20:209-222

GarciaFayos P, Cerda A (1997) Seed losses by surface wash in degraded Mediterranean environments. Catena 29:73-83

García-Fayos P, Gulias J, Martínez J, Marzo A, Melero JP, Traveset A, Veintimilla P, Verdú M, Cerdán V, Gasque M, Medrano H (2001) Bases ecológicas para la recolección, almacena-miento y germinación de semillas de especies de uso forestal de la comunidad 
Valenciana. Banc de Llavors Forestals (conselleria de Medi Ambient, Generalitat Valenciana), Valencia, $82 \mathrm{pp}$

Gil L, Lopez R, Garcia-Mateos A, Gonzalez-Doncel I (2009) Seed provenance and fire-related reproductive traits of Pinus pinaster in central Spain. Int J Wildland Fire 18:1003-1009

Herranz JM, MartinezSanchez JJ, Marin A, Ferrandis P (1997) Postfire regeneration of Pinus halepensis Miller in a semiarid area in Albacete province (southeastern Spain). Ecoscience 4:86-90

Madrigal J, Hernando C, Guijarro M, Vega JA, Fonturbel T, PerezGorostiaga P (2010) Smouldering fire-induced changes in a Mediterranean soil (SE Spain): effects on germination, survival and morphological traits of 3-year-old Pinus pinaster Ait. Plant Ecol 208:279-292

Maia P, Pausas JG, Arcenegui V, Guerrero C, Pérez-Bejarano A, Mataix-Solera J, Varela MET, Fernandes I, Pedrosa ET, Keizer JJ (2012) Wildfire effects on the soil seed bank of a maritime pine stand - the importance of fire severity. Geoderma. doi:10.1016/j. geoderma.2012.02.001

Martínez-Sanchez JJ, Ferrandis P, de Las Heras J, Herranz JM (1999) Effect of burnt wood removal on the natural regeneration of Pinus halepensis after fire in a pine forest in Tus valley (SE Spain). For Ecol Manag 123:1-10

McDonald JH (2009) Handbook of biological statistics. Sparky, Baltimore

Nathan R, Ne'eman G (2004) Spatiotemporal dynamics of recruitment in Aleppo pine (Pinus halepensis Miller). Plant Ecol 171:123-137

Ne'eman G, Izhaki I (1998) Stability of pre- and post-fire spatial structure of pine trees in Aleppo pine forest. Ecogr 21:535-542

Oliveira AC, Pereira JS, Correia AV (2000) A silvicultura do Pinheiro Bravo. Centro Pinus, Porto. 113p

Otto R, Garcia-del-Rey E, Munoz PG, Fernandez-Palacios JM (2010) The effect of fire severity on first-year seedling establishment in a Pinus canariensis forest on Tenerife, Canary Islands. Eur J For Res 129:499-508

Pausas JG, Ouadah N, Ferran A, Gimeno T, Vallejo R (2003) Fire severity and seedling establishment in Pinus halepensis woodlands, eastern Iberian Peninsula. Plant Ecol 169:205-213

Pausas JG, Ribeiro E, Vallejo R (2004) Post-fire regeneration variability of Pinus halepensis in the eastern Iberian Peninsula. For Ecol Manag 203:251-259

Pausas JC, Llovet J, Rodrigo A, Vallejo R (2008) Are wildfires a disaster in the Mediterranean basin?-a review. Int $\mathrm{J}$ Wildland Fire 17:713-723

Perez B, Moreno JM (1998) Fire-type and forestry management effects on the early postfire vegetation dynamics of a Pinus pinaster woodland. Plant Ecol 134:27-41

Reyes O, Casal M (2001) The influence of seed age on germinative response to the effects of fire in Pinus pinaster, Pinus radiata and Eucalyptus globulus. Ann Sci 58:439-447
Reyes O, Casal M (2002) Effect of high temperatures on cone opening and on the release and viability of Pinus pinaster and $P$. radiata seeds in NW Spain. Ann For Sci 59:327-334

Reyes O, Casal M (2004) Effects of forest fire ash on germination and early growth of four pinus species. Plant Ecol 175:81-89

Rivas-Martínez S, Díaz TE, Fernández-González F, Izco J, Lousã M, Penas A (2002) Vascular plant communities of Spain and Portugal. Addenda to the syntaxonomical checklist of 2001. Itiner Geobotanica 15:5-432

Santos AS (2010) Efeitos dos fogos florestais na dinâmica do azoto e carbono dos solos, na região centro de Portugal. Unpublished MSc thesis, Agrarian High School (ESAC), Coimbra

Saracino A, Pacella R, Leone V, Borghetti M (1997) Seed dispersal and changing seed characteristics in a Pinus halepensis Mill forest after fire. Plant Ecol 130:13-19

Silva J, Moreira F, Vaz P, Catry F, Ferreira P (2009) Assessing the relative fire proneness of different forest types in Portugal. Plant Biosyst 143:597-608

SNIRH (2011) www.snirh.pt. Sistema Nacional de Informação de Recursos Hídricos. Acessed November 2011

Tapias R, Climent J, Pardos JA, Gil L (2004) Life histories of Mediterranean pines. Plant Ecol 171:53-68

Thanos CA, Skordilis A (1987) The effects of light, temperature and osmotic-stress on the germination of Pinus halepensis and Pinus brutia seeds. Seed Sci Technol 15:163-174

Thanos CA, Daskalakou EN, Nikolaidou S (1996) Early post-fire regeneration of a Pinus halepensis forest on Mount Parnis, Greece. J Veg Sci 7:273-280

Torres O, Calvo L, Valbuena L (2006) Influence of high temperatures on seed germination of a special Pinus pinaster stand adapted to frequent fires. Plant Ecol 186:129-136

Trabaud L, Michels C, Grosman J (1985) Recovery of burnt Pinus halepensis Mill. forests. II. Pine reconstruction after wildfire. For Ecol Manag 13:167-179

Tutin TG, Heywood VH, Burges DH, Valentine DH, Moore DM, Walters SM, Webb DA (eds) (1964-1980) Flora Europaeae. Cambridge University Press, Cambridge

Ubeda X, Outeiro LR, Sala M (2006) Vegetation regrowth after a differential intensity forest fire in a Mediterranean environment, northeast Spain. Land Degrad Dev 17:429-440

Vega JA, Fernandez C, Perez-Gorostiaga P, Fonturbel T (2008) The influence of fire severity, serotiny, and post-fire management on Pinus pinaster Ait. recruitment in three burnt areas in Galicia (NW Spain). For Ecol Manag 256:1596-1603

Vega JA, Fernandez C, Perez-Gorostiaga P, Fonturbel T (2010) Response of maritime pine (Pinus pinaster Ait.) recruitment to fire severity and post-fire management in a coastal burned area in Galicia (NW Spain). Plant Ecol 206:297-308

WRB (2007) http://www.fao.org/nr/land/soils/soil/wrb-soil-maps/en/. Accessed November 2011 